\title{
Effectiveness of Primary Angioplasty in the Treatment of Acute Myocardial Infarction. Analysis of In-hospital and Late Outcomes in 135 Consecutive Cases
}

\author{
Rogério Sarmento Leite, Ana Maria Krepsky, Carlos A.M. Gottschall
}

Porto Alegre, RS - Brazil

\begin{abstract}
Objective - Evaluate early and late evolution of patients submitted to primary coronary angioplasty for acute myocardial infarction.
\end{abstract}

Methods - A prospective study of 135 patients with acute myocardial infarction submitted to primary transcutaneous coronary angioplasty (PTCA). Success was defined as TIMI 3 flow and residual lesion $<50 \%$. We performed statistical analyses by univariated, multivariated methods and survival analyze by Kaplan-Meier.

Results - PTCA success rate was $78 \%$ and early mortality 18,5\%. Killip classes III and IV was associated to higher mortality, odds ratio 22.9 (95\% CI: 5,7 to 91,8) and inversely related to age $<75$ years $(O R=0,93 ; 95 \% C I$ : 0.88 to 0.98). If we had chosen success flow as TIMI 2 and had excluded patients in Killip III/IV classes, success rate would be $86 \%$ and mortality $8 \%$. The survival probability at the end or study, follow-up time $142 \pm 114$ days, was $80 \%$ and event free survival 35\%. Greater survival was associated to stenting $(O R=0.09 ; 0.01$ to 0.75$)$ and univessel disease $(O R=0.21 ; 0.07$ to 0.61$)$.

Conclusion - The success rate was lower and mortality was higher than randomized trials, however similar to that of non randomized studies. This demonstrated the efficacy of primary PTCA in our local conditions.

Key words: ischemic heart disease, acute myocardial infarction, primary percutaneous transluminal coronary angioplasty

Instituto de Cardiologia do Rio Grande do Sul/Fundação Universitária de Cardiologia

Mailing address: Carlos A.M. Gottschall - IC/FUC - Av. Princesa Isabel, 395 90620-001 - Porto Alegre, RS, Brazil - E-mail: pesquisa@cardnet.tche.br English version by Stela Maris C. e Gandour
Ischemic heart disease stands out among the disorders of the cardiovascular system because of its high prevalence and its impact on mortality in the general population. Ischemic heart disease accounts for $34 \%$ of all mortality causes, with similar figures for the entire American continent; in Brazil, it accounts for 300,000 deaths per year or 820 deaths per day. We can speak of an epidemic, which replaces the infectious diseases that predominated as the major cause of death until the middle of the century ${ }^{1}$.

Acute myocardial infarction is the most severe form of presentation of ischemic heart disease. Even though the risk of death decreases as days go by after the event, $20 \%$ to $30 \%$ of patients are estimated to die in the initial hours of acute myocardial infarction, and, of these, $50 \%$ die in the first hour of clinical onset ${ }^{2}$

From the historical point of view, since the beginning of its use, coronary thrombolysis with its diverse agents has been shown to be effective in coronary reperfusion in randomized clinical trials. The result is a decrease in the area of infarct, and improvement in the ventricular function, which leads to better indices of survival and reduced morbidity and mortality ${ }^{3-16}$. Other randomized and nonrandomized clinical trials have suggested that primary angioplasty may result in a higher rate of coronary reperfusion and patency, a lower index of reoclusion and of systemic bleedings, a shorter time of hospitalization, and a reduction in hospital costs; on the other hand, other studies have shown no significant difference ${ }^{17-32}$.

However, primary angioplasty is well known to be of difficult and limited applicability in our environment, because of our geographical, political, and, mainly, economic situation, which limits the access to the procedure to a small part of the population. In our country, few are the hospitals and physicians skilled to perform interventional procedures, and, even fewer are those who can use them in emergency situations. In addition, due to the inadequate follow-up and low socioeconomic level of our patients, the advantages of the cost-benefit ratio of the procedure obtained in 
the medium- and long-term in the large studies are not always reproducible.

The problem in question is to assess whether primary angioplasty is feasible, and whether it is adaptable to the reality of a given community, involving the concept of effectiveness and not that of efficacy.

Therefore, we find plainly justified a study whose major objective is to assess the results, complications, and evolution of patients with acute myocardial infarction treated with primary angioplasty in an institution with important representation in our country.

\section{Methods}

We conducted a contemporary noncontrolled cohort study, in which the factor studied was being part of a population that underwent primary angioplasty for the treatment of acute myocardial infarction at the Instituto de Cardiologia do Rio Grande do Sul/Fundação Universitária de Cardiologia during the period from 3/1/97 to 9/30/98.

We enrolled the patients in a consecutive manner, and the decision to use primary angioplasty as therapeutics of revascularization was the responsibility of the assisting team.

The patients presenting for the procedure with a duration of myocardial infarction shorter than 12 hours were included in the study, even patients in cardiogenic shock, previous infarction, and with a previous revascularization procedure were included.

The material used was that available at the laboratory, which may have varied according to the supplier and market prices. The diameter of the balloon varied according to the diameter of the culprit artery, always aiming at the proportion of $1: 1$. The thickness of the guide wire was 0.014 inches, and the guiding catheters had a diameter of 8 French.

All patients received aspirin at the dosage of 100 to $500 \mathrm{mg}$, and 10,000 to 15,000 units of heparin prior to the procedure. The team in charge decided the use of other medications, such as ticlopidine and glycoprotein inhibitors, and stent implantation. The procedure was performed with no control of the coagulation tests, and the technique, time of inflation, and pressure of the balloon were decided by the physician in charge of the procedure. Except when contraindications existed, all patients were maintained for at least 24 hours with heparin at the dosage of 20,000 to 25,000 units per day. After the procedure, the patients were referred to the coronary unit or returned to the emergency department.

All complications were registered for further analysis. Doppler echocardiography was always performed before hospital discharge to assess the ventricular function and the regional motility of the heart. The analysis of ventricular function was performed through the conventional manner and the method of acoustic quantification, which, according to Castro's report ${ }^{33}$, has a high correlation and concordance with the information obtained on cineangioventriculography.

After hospital discharge, the patients were scheduled to return for an ambulatory clinical visit and a new echocar- diography in 6 to 12 months. In all patients who had completed the follow-up, echocardiography was repeated with acoustic quantification, preferably performed by the same examining physician. New coronary and noncoronary events, the patient's clinical condition, and the need for a new revascularization procedure or hospitalization were also recorded. Those patients who missed the follow-up visits were contacted by telephone, telegram, or letter, and advised to seek the hospital for assessment.

The angiographic analysis, due to its subjectiveness, was carried out by 2 interventional cardiologists, and, in case of disagreement, it was referred for a third opinion.

Data were stored in EPI INFO data bank version 6.0. Bivariate analysis was performed for the variables considered possible risk factors for mortality or for those considered potential confounders. The $t$ test was used for continuous variables, and the chi-square test or Fisher exact test was used for categorical variables.

To assess the factors determining major and minor outcomes, models of logistic regression were used in which clinically significant variables were included according to theoretical assumptions.

Assessment of survival was performed with the aid of the Kaplan-Meier method using life tables and graphs, which described the combined events during the total follow-up of the patients.

The values for ventricular function obtained through echocardiography performed before and after the procedure were compared using the $t$ test for paired samples.

In all analyses, a critical alpha $<0.05$ was considered for determining statistical significance.

\section{Results}

In-hospital phase - During the period from 3/1/97 to 9/ 30/98, 858 patients were admitted to the Instituto de Cardiologia do Rio Grande do Sul with the diagnosis of acute myocardial infarction. Of these, $44 \%$ received the conventional treatment, $41 \%$ underwent thrombolysis, and $15 \%$ were referred for primary angioplasty. The study's sample comprised 135 consecutive patients. The general characteristics are shown in table I.

The time estimated between pain onset and the beginning of the procedure was $3.2 \pm 2.8 \mathrm{~h}$, ranging from a minimum of $10 \mathrm{~min}$ to a maximum of $12 \mathrm{~h}$; the time period between hospital admission and inflation of the balloon was $86 \pm 43 \mathrm{~min}$.

The reason for performing primary angioplasty as a therapeutical option for acute myocardial infarction was due to the preference of the team assisting the patient in $44 \%$ of the cases, followed by absolute contraindication to thrombolysis in $22.2 \%$, cardiogenic shock in $11.9 \%$, reinfarction in $11.1 \%$, and other causes in $10.4 \%$.

Success in the procedure was considered the obtainment of TIMI 3 flow with residual stenosis lower than $50 \%$ in a patient who had survived acute myocardial infarction. A success rate of $78 \%$ was obtained. In 22 (16\%) patients, stents were implanted because of unsatisfactory results of 


\begin{tabular}{|c|c|c|c|}
\hline \multicolumn{4}{|c|}{ Table I - General characteristics of the patients ( $n=135$ ) } \\
\hline \multicolumn{2}{|c|}{ Categorical variables } & $\mathrm{n}$ & $\%$ \\
\hline \multicolumn{2}{|l|}{ Male sex } & 86 & 63.7 \\
\hline \multicolumn{2}{|c|}{ Killip class prior to the procedure - I-II } & 118 & 87.4 \\
\hline & - III-IV & 17 & 12.6 \\
\hline \multicolumn{2}{|c|}{ Culprit vessel - anterior descending artery } & 60 & 44.4 \\
\hline \multicolumn{2}{|c|}{ - right coronary artery } & 51 & 37.8 \\
\hline \multicolumn{2}{|r|}{ - circumflex artery } & 13 & 9.6 \\
\hline \multicolumn{2}{|c|}{ - others } & 11 & 8.2 \\
\hline \multicolumn{2}{|c|}{ TIMI flow prior to the procedure - 0 - II } & 124 & 92.5 \\
\hline \multicolumn{2}{|c|}{- III } & 10 & 7.5 \\
\hline \multirow[t]{2}{*}{ Infarct site } & - Anterior & 67 & 49.6 \\
\hline & - Nonanterior & 68 & 51.4 \\
\hline & 62 & 45.9 \\
\hline \multicolumn{2}{|c|}{$\begin{array}{r}\text { Number of vessels involved }-1 \\
-2 \text { or more }\end{array}$} & 73 & 54.1 \\
\hline \multicolumn{2}{|c|}{ Use of stents } & 22 & 16.3 \\
\hline \multicolumn{2}{|c|}{ Use of intraaortic balloon } & 10 & 7.4 \\
\hline \multirow[t]{6}{*}{ Previous history - } & - systemic hypertension & 64 & 47.4 \\
\hline & - tobacco use & 52 & 38.5 \\
\hline & - diabetes mellitus & 27 & 20 \\
\hline & - dyslipidemias & 23 & 17 \\
\hline & - acute myocardial infarction & 20 & 14.8 \\
\hline & - obesity & 16 & 11.8 \\
\hline \multicolumn{2}{|c|}{ Continuous variables } & \multicolumn{2}{|l|}{$\mathrm{M} \pm \mathrm{DP}$} \\
\hline \multicolumn{2}{|l|}{ age (years) } & \multicolumn{2}{|c|}{$61.8 \pm 12.1$} \\
\hline \multicolumn{2}{|c|}{ mean blood pressure } & \multicolumn{2}{|l|}{$88.5 \pm 31$} \\
\hline \multicolumn{2}{|c|}{ heart rate (bpm) } & \multicolumn{2}{|l|}{$76 \pm 19$} \\
\hline \multicolumn{2}{|l|}{ delay (h) } & \multicolumn{2}{|l|}{$3.2 \pm 2.8$} \\
\hline
\end{tabular}

the conventional angioplasty. No patient received glycoprotein IIb/IIIa inhibitors.

In-hospital mortality was $18.5 \%$, corresponding to $25 \mathrm{pa}-$ tients, $54 \%$ of whom died during the procedure. Table II shows the bivariate associations of the different factors with this worse in-hospital evolution. Functional class, a mean blood pressure lower than $60 \mathrm{mmHg}$, and age $\geq 75$ years old were significantly associated with higher mortality. The variables independently associated with in-hospital mortality were analyzed with a model of multiple logistic regression (tab. III).

The mean duration of hospitalization was $8.5 \pm 6$ days (minimum of 1 day and maximum of 38 days). Cardiac complications occurred in $21(19.1 \%)$ patients, postinfarction angina being the most prevalent, occurring in $9(8.2 \%)$ patients, followed by heartfailure in $8(7.3 \%)$ patients, reinfarction in $3(2.7 \%)$ patients, and acute mitral insufficiency in only $1(0.9 \%)$ patient. In regard to the need for new revascularization procedures, new myocardial revascularization was required in 7 (6.3\%) patients, and new primary angioplasty in $3(2.7 \%)$ patients.

Of the 110 patients who survived, $100(74.1 \%)$ were discharged from the hospital with no symptoms and requiring no additional procedures. In 98 patients, echocardiography with acoustic quantification was performed to assess the ventricular function on the day of hospital discharge, and the mean ejection fraction of the patients was $49.5 \% \pm 12 \%$.

Late evolution - Only a small number of patients ( 26 out of the 100 patients who were discharged asymptomatic from the hospital) underwent control coronary angiogra-

\begin{tabular}{|c|c|c|c|}
\hline \multicolumn{4}{|c|}{$\begin{array}{l}\text { Table II - Comparison in regard to mortality - bivariate } \\
\text { analysis }\end{array}$} \\
\hline Variable & $\begin{array}{l}\text { Death } \\
-\mathrm{n}(\%)\end{array}$ & $\begin{array}{l}\text { Non death } \\
-\mathrm{n}(\%)\end{array}$ & $\mathrm{p}$ \\
\hline \multicolumn{4}{|l|}{ Sex } \\
\hline Male & $14(16.3)$ & $72(83.7)$ & 0.490 \\
\hline Female & $11(22.4$ & $38(77.6)$ & \\
\hline \multicolumn{4}{|l|}{ Age } \\
\hline$<75$ years & $19(15.7)$ & $102(84.3)$ & 0.024 \\
\hline$\geq 75$ years & $6(42.8)$ & $8(57.2)$ & \\
\hline \multicolumn{4}{|l|}{ Heart rate (bpm) } \\
\hline$<100$ & $21(16.9)$ & $103(83.1)$ & 0.121 \\
\hline$\geq 100$ & $4(36.4)$ & $7(63.6)$ & \\
\hline \multicolumn{4}{|c|}{ Mean blood pressure (mmHg) } \\
\hline$<60^{\circ}$ & $10(66.7)$ & $5(33.3)$ & 0.001 \\
\hline$\geq 60$ & $15(12.5)$ & $105(87.5)$ & \\
\hline \multicolumn{4}{|c|}{ Killip prior to the procedure } \\
\hline I-II & $12(10.2)$ & $106(89.8)$ & 0.001 \\
\hline III-IV & $13(76.5)$ & $4(23.5)$ & \\
\hline \multicolumn{4}{|l|}{ Delay (h) } \\
\hline$<3$ & $9(14.1)$ & $55(85.9)$ & 0.268 \\
\hline$\geq 3$ & $16(22.5)$ & $55(77.5)$ & \\
\hline \multicolumn{4}{|l|}{ Culprit vessel } \\
\hline $\begin{array}{l}\text { descending } \\
\text { anterior }\end{array}$ & $10(16.6)$ & $52(83.9)$ & 0.657 \\
\hline others & $15(20.5)$ & $58(79.5)$ & \\
\hline \multicolumn{4}{|c|}{ TIMI flow prior to the procedure* } \\
\hline 0-I-II & $25(20.2)$ & $99(79.8)$ & 0.207 \\
\hline III & 0 & $10(100)$ & \\
\hline \multicolumn{4}{|l|}{ Vessels involved } \\
\hline 1 & $10(16.1)$ & $52(83.9)$ & 0.673 \\
\hline 2 or more & $15(20.5)$ & $58(79.5)$ & \\
\hline \multicolumn{4}{|l|}{ Infarct site } \\
\hline Anterior & $13(19.4)$ & $54(80.6)$ & 0.666 \\
\hline Non anterior & $12(17,6)$ & $56(82,4)$ & \\
\hline \multicolumn{4}{|c|}{ Use of intra-aortic balloon } \\
\hline Yes & $4(40)$ & $6(60)$ & 0.088 \\
\hline No & $21(16.8)$ & $104(83.2)$ & \\
\hline \multicolumn{4}{|l|}{ Use of stent } \\
\hline Yes & $1(4.5)$ & $21(95.5)$ & \\
\hline No & $24(21.2)$ & $89(78.8)$ & 0.076 \\
\hline
\end{tabular}

\begin{tabular}{|lcccc|}
\hline \multicolumn{5}{|c|}{ Table III - Factors that influence in-hospital mortality - model of } \\
multiple logistic regression
\end{tabular}

phy, because this exam was not part of the protocol and it was exclusively up to the assisting team to decide upon its performance; the mean period of time for the new test was 98 days. Ten (38.5\%) patients maintained the angiographic findings unaltered. Restenosis obstructing more than $50 \%$ of the lumen of the vessel occurred in $8(30.8 \%)$ patients, and reocclusion in $5(19.2 \%)$ of the arteries treated. Progression of the disease in a site other than that dilated was observed in $3(11.5 \%)$ patients. 
Before the date scheduled for reassessment, major clinical events occurred, and they are listed in table IV.

Of the 100 patients who were discharged asymptomatic, 26 had 1 event, and 4 were lost or were withdrawn from the study; therefore, the clinical reassessment proposed was carried out in 70 patients, who represented $51.2 \%$ of the initial sample. Figure 1 shows the Kaplan-Meier curve depicting total survival until the date of the new medical visit, and survival free from an event until the end of the study. The mean follow-up was 142.9 \pm 114.5 (median of 181.0) days. At the time of clinical follow-up, $57(81.4 \%$ ) patients out of the 70 whoremained under observation were asymptomatic, $9(12.8 \%)$ had angina pectoris on medium and major exertion, and $4(5.8 \%)$ had symptoms of heart failure on medium and major exertion.

Echocardiography with acoustic quantification was performed in all 70 patients who returned for follow-up with no clinical events. The mean ejection fraction was $48.4 \% \pm 11.9 \%$. It is noteworthy that, in these cases, no statistically significant difference was observed between the echocardiographic measurement at the time of hospital discharge (49.5\%) and that at the time of the final follow-up ( $48.7 \%$ ), showing that no increase in ventricular function occurred in those individuals who survived free from events in a global analysis.

The factors associated with worse clinical evolution (major events) through the bivariate analysis are shown in table $\mathrm{V}$. A reduction in the rate of events was only observed in the patients with stent implantation and coronary disease

\begin{tabular}{|lc|}
\hline \multicolumn{2}{|c|}{ Table IV - Clinical outcomes } \\
\hline Outcome & $\mathrm{N}$ \\
\hline Myocardial revascularization & 10 \\
Reinfarction & 5 \\
New PTCA with stent & 4 \\
Unstable angina & 2 \\
Acute pulmonary edema & 1 \\
New conventional PTCA & 1 \\
Stroke & 1 \\
Deaths & 2 \\
\hline
\end{tabular}

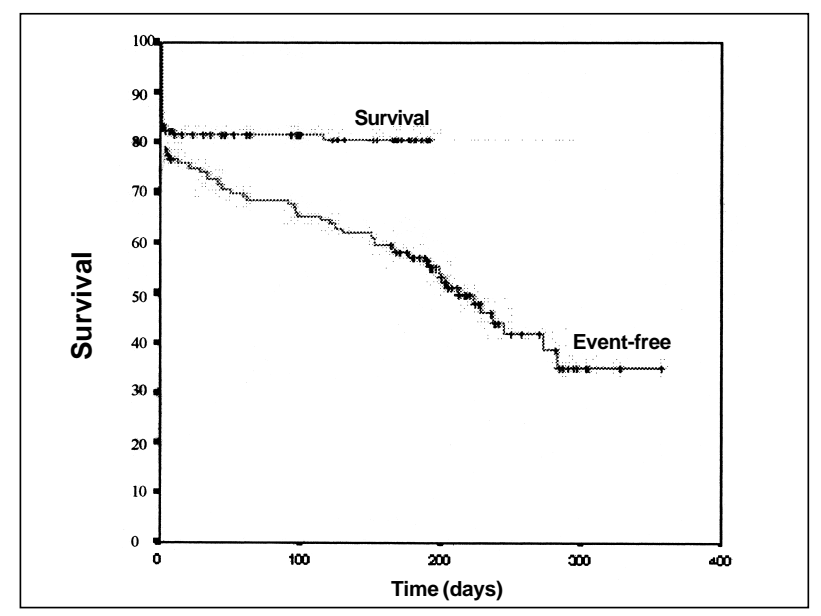

Fig. 1 - Total survival and event-free survival during the follow-up.

\begin{tabular}{|c|c|c|c|}
\hline \multicolumn{4}{|c|}{$\begin{array}{c}\text { Table V - Comparison in regard to late outcome - bivariate } \\
\text { analysis }\end{array}$} \\
\hline Variable & $\begin{array}{l}\text { Event-free } \\
\mathrm{n}(\%)\end{array}$ & $\begin{array}{l}\text { Other events } \\
\mathrm{n}(\%)\end{array}$ & $\mathrm{P}$ \\
\hline \multicolumn{4}{|l|}{ Sex } \\
\hline Male & $47(74,6)$ & $16(25,4)$ & 0,628 \\
\hline Female & $22(68,9)$ & $10(31,3)$ & \\
\hline \multicolumn{4}{|l|}{ Age } \\
\hline$<75$ years & $64(72,7)$ & $24(27,3)$ & 1,000 \\
\hline$\geq 75$ years & $69(71,4)$ & $26(28,6)$ & \\
\hline \multicolumn{4}{|c|}{ Killip prior to the procedure } \\
\hline I-II & $66(72,5)$ & $25(27,5)$ & 1,000 \\
\hline III-IV & $3(75)$ & $1(25)$ & \\
\hline \multicolumn{4}{|c|}{ Ejection fraction at the time of hospital discharge } \\
\hline$<40$ & $12(66,7)$ & $6(23,3)$ & 0,554 \\
\hline$\geq 40$ & $54(75)$ & $18(25)$ & \\
\hline \multicolumn{4}{|l|}{ Use of stent } \\
\hline Yes & $18(94,7)$ & $1(5,3)$ & 0,019 \\
\hline No & $51(67,1)$ & $25(32,9)$ & \\
\hline \multicolumn{4}{|l|}{ Delay (h) } \\
\hline$<3$ & $36(73,4)$ & $13(26,6)$ & 1,00 \\
\hline$\geq 3$ & $33(84,6)$ & $13(15,4)$ & \\
\hline \multicolumn{4}{|l|}{ Vessels involved } \\
\hline 1 & $38(86,4)$ & $6(13,6)$ & 0,05 \\
\hline 2 or more & $31(60,8)$ & $20(39,2)$ & \\
\hline \multicolumn{4}{|l|}{ Infarct site } \\
\hline Anterior & $34(69,4)$ & $15(30,6)$ & 0,624 \\
\hline Non-anterior & $35(76,1)$ & $11(23,9)$ & \\
\hline \multicolumn{4}{|c|}{ Success of the procedure } \\
\hline Yes & $61(75,3)$ & $20(24,7)$ & 0,197 \\
\hline No & $8(57,1)$ & $6(42,9)$ & \\
\hline
\end{tabular}

restricted to 1 vessel. These variables, which associated with a higher incidence of events in an independent manner, were analyzed with a multiple logistic regression model (tab. VI). Figure 2 shows, with the aid of a Kaplan-Meier curve, the best evolution during the period of observation of those patients who had received stents during primary angioplasty in regard to major events.

\section{Discussion}

Primary angioplasty is not the most common treatment for myocardial reperfusion at our institution. Primary angioplasty was the choice in the most severely ill patients, in those at higher risk, in those with contraindications to other procedures, and in those cases in which the soliciting physician was certain about that being the best method.

In regard to the predominance of the male sex, mean age, time delay for initiation of treatment, vessel treated,

\begin{tabular}{|c|c|c|c|c|}
\hline \multicolumn{5}{|c|}{$\begin{array}{l}\text { Table VI - Factors that influenced positively to reduce late events - } \\
\text { model of multiple logistic regression }\end{array}$} \\
\hline Variable & $\beta$ & $\mathrm{P}$ & $\beta^{(\mathrm{Exp.})}$ & $\begin{array}{c}\text { Confidence } \\
\text { interval }\end{array}$ \\
\hline $\begin{array}{l}\text { Only } 1 \\
\text { vessel involved }\end{array}$ & $-1,551$ & 0,0042 & 0,211 & $0,07-0,61$ \\
\hline Use of stent & $-2,380$ & 0,0264 & 0,092 & $0,01-0,75$ \\
\hline
\end{tabular}




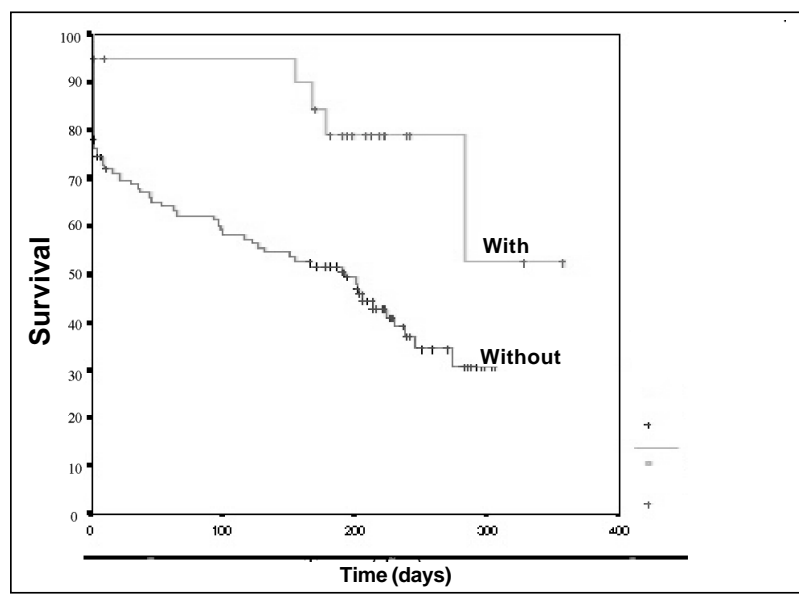

Fig. 2 - Event-free survival of patients who underwent stent implantation and of those who did not.

location of the infarct, and initial flow assessed according to the TIMI classification ${ }^{34}$, data are similar to those found in other series reported in the literature ${ }^{35-37}$. On the other hand, in regard to the previous pathological history, hypertension, tobacco use, diabetes mellitus, dyslipidemia, previous infarction, and obesity, these data are largely variable when compared with those of other series ${ }^{28,35,38}$. This may be due to the fact that this was a heterogeneous nonrandomized population, and, therefore, not reliably representing all those patients with acute myocardial infarction.

The high number of patients with Killip III and IV functional classes and with mean blood pressure below $60 \mathrm{mmHg}$ in our study is noteworthy. These patients, who were excluded from or accounted only for a reduced part of the sample in most series and clinical trials ${ }^{25-26,35,39,40}$, constituted approximately $13 \%$ of our study's sample and directly contributed to the higher number of unsuccessful cases, mortality, and worse evolution.

The reason for performing primary angioplasty for the treatment of acute myocardial infarction is difficult to compare, because most studies are randomized, and, consequently, only those 2 alternatives exist. Smyth et al ${ }^{38}$, in their cohort study in New Zealand, report data very similar to that here presented. Therefore, it seems that, in nonrandomized studies, the reasons are similarly distributed, considering local rules and routines.

The in-hospital mortality of $18.5 \%$ and the angiographic success of $78 \%$ are not in total accordance with the results reported in the literature, which range from $0 \%$ to $10 \%$ and from $73 \%$ to $98 \%$, respectively ${ }^{24-29,35,37-39,41}$. However, we should consider that this cohort assesses the patients in a global manner, without excluding the most severely ill ones with Killip III and IV functional classes, and that it uses a very strict criterion for the definition of success of a procedure, which is exclusively the obtainment of TIMI 3 flow, with residual stenosis lower than $50 \%$ in patients surviving an event. The clinical trials are far less strict in defining success, considering only the patients undergoing the procedure and not the total sum of the randomized patients.
In addition, in these clinical trials, the patients, in whom TIMI 2 flow is obtained, are included in the success group, and, frequently, those patients in poorer clinical condition are not considered. If we excluded the patients with Killip III and IV functional classes, and considered TIMI 2 flow as successful, the rate of success of the procedure in our series of patients would increase to $86 \%$, and mortality would drop to approximately $8 \%$. These indices are close to those obtained in noncontrolled studies ${ }^{29,41}$ and to those provided by the CENIC records ${ }^{42}$, in which the general success of primary balloon angioplasty is $84 \%$.

Only the following parameters were significantly related to higher mortality: age $\geq 75$ years, Killip III or IV functional class, mean blood pressure, and failure during the procedure. To avoid the effect of colinearity, blood pressure was excluded from the model of multiple logistic regression, and, due to conceptual reasons, because survival was a criterion of success of the procedure, angiographic success was also excluded to avoid a confounding bias. These findings are supported by those of the PAMI study ${ }^{23}$, MITI study ${ }^{29}$, and the studies by Garcia et al ${ }^{39}$ and Azmus ${ }^{41}$, which proved that advanced age was a variable independently associated with higher mortality. Functional class, as defined by the criteria of Killip-Kimbal at hospital admission, was the major determinant of worse in-hospital evolution. Mortality in this subgroup was $76.5 \%$. These results were similar to those reported in the literature ${ }^{43}$ for patients in cardiogenic shock, but different from those reported in the SHOCK clinical trial ${ }^{44}$, in which mortality dropped to $46 \%$, with a better benefit for the nonelderly population. The occurrence of $54.4 \%$ of the deaths in the most acute phase of acute myocardial infarction suggests the presence of extensive myocardial damage.

Better results are known to be directly related to the duration and quality of the procedure. Well-known data from clinical trials with thrombolytic agents ${ }^{1}$ show a linear reduction in mortality as soon as the treatment is started. The same may be properly applied to primary angioplasty ${ }^{45}$. The mean time duration in this series was $3.2 \pm 2.8$ hours, which was longer than that reported with the use of thrombolytic agents ${ }^{32}$, which varied from 20 to $84 \mathrm{~min}$, but similar to that obtained with primary angioplasty, when the time elapsed from symptom onset to inflation of the balloon was considered. Quality of reperfusion is a synonym for flow restoration, expressed by TIMI ${ }^{34}$; it is currently a consensus that obtainment of TIMI 3 flow is associated with a better prognosis and greater preservation of the cardiac muscle than that of TIMI 2 flow ${ }^{46}$. Grines et al ${ }^{47}$ have shown in a metaanalysis that when TIMI 3 flow is obtained, a reduction up to $46 \%$ in mortality occurs as compared with that in TIMI 2 flow. These results are more evident in subgroups of diabetic patients with infarction of the anterior wall. Therefore, we emphasize the objective of this series to value as successful only the obtainment of plain anterograde coronary flow (TIMI 3 flow).

Even though mortality does not change, the occurrence of complications in the in-hospital phase, specifically angina or reinfarction, is known to be lower in patients undergoing primary angioplasty as compared with those 
undergoing thrombolysis ${ }^{32}$. In our study, these complications added to $10.9 \%$, which is a result similar to the best results obtained in clinical trials, which ranged from 9 to $15 \%$. Therefore, excluding the deaths, which characterized a more severely ill population, our population is in accordance with the selected patients of other studies.

The relation between coronary patency and preservation of ventricular function is well defined. Because we believe that a long-term beneficial effect with recovery of the hibernating and stunned myocardium and a reduction in the ventricular remodeling exist, we chose a later comparative analysis. The mean value of ventricular function of $49.5 \% \pm 12 \%$ obtained prior to hospital discharge in the surviving patients means that this is a group with a favorable prognosis. These results are similar to the $48 \%$ reported by Garcia et $\mathrm{al}^{39}$ and the $49 \%$ of the TIMI $2 \mathrm{~A}$ study ${ }^{20}$, but are below the $53 \%$ reported by Gibbons ${ }^{25}$ and the $56 \%$ of the TAMI study ${ }^{48}$.

The mortality rate in the first year for those patients who survived free from events in the in-hospital phase was $2 \%$. This result is similar to that reported by several authors and compiled by Stone ${ }^{49}$, which ranged from $1 \%$ to $5 \%$, in a follow-up period from 6 to 24 months. On the other hand, the late results of the PAMI study have shown a mortality rate of $1.1 \%$ in 6 months ${ }^{50}$ and of $6.2 \%$ accumulated in 24 months, excluding the in-hospital events ${ }^{51}$. Garcia et al ${ }^{39} \mathrm{re}-$ ported a mortality rate of $1.8 \%$ by the end of 6 months, and Zijlstra et al ${ }^{52}$ reported a mortality rate of $3.9 \%$ in 18 months. When the results of these latter series are compared with ours, one may see that the mortality rate in our series by the end of 12 months is low. Therefore, those patients who were discharged asymptomatic comprised a group very distinct from those with poor in-hospital evolution, because they had a high rate of survival, which may be explained by the fact that most of this group had normal ventricular function and good clinical management.

The incidence of reinfarction was $5 \%$ by the end of the observation period. In the study by Garcia et al $^{39}$, this rate was $3.7 \%$ in 6 months. In the PAMI study, the recurrence rate of nonfatal acute myocardial infarction in 6 months was $2.6 \%{ }^{50}$, and $10.8 \%$ by the end of 2 years ${ }^{51}$. Zijlstra et al ${ }^{52}$ reported lower figures with $2.6 \%$ in 18 months. Therefore, our population seems to behave in accordance with that in other studies in this regard.

The need for a new percutaneous or surgical revascularization procedure is another interesting point. In our series, the total of cases of new angioplasty with or without stent implantation or need for an aortocoronary bypass is $15 \%$, which is similar to that reported by Garcia et al ${ }^{39}$ in 6 months, but lower than the $17.9 \%$ and $45.7 \%$ observed in the 6-month ${ }^{50}$ and 2 -year ${ }^{51}$ follow-up of the PAMI study, respectively. Once again, the good outcome of this cohort study as compared with others is noteworthy.

In our study, we classified stroke, anginal pain, and heart failure requiring hospital admission as major cardiovascular events, unlike the large studies, which do not characterize these events like we did. They represented an in- crease of $4 \%$ in events by the end of 12 months and stressed the strictness in assessing the outcomes in our study.

The sum of all late events in our series was $26 \%$, but it is interesting that most of them $(96 \%)$ occurred in patients who had undergone conventional angioplasty with no stent implantation, suggesting that coronary endoprostheses are a factor of protection in reducing events. Preliminary studies have already pointed out this trend ${ }^{53}$, especially in optimizing the results of less satisfactory conventional angioplasties. Short clinical trials have shown the potential superiority of stent implantation upon conventional angioplasty with a combined reduction in mortality, restenosis, and need for new revascularization in the group treated with stent as compared with that treated with balloon. Larger studies have confirmed this trend. The FRESCO trial ${ }^{54}$ has shown a reduction of $61 \%$ in the detection of angiographic restenosis, which has determined a reduction of up to $72 \%$ in the need for new revascularization of the vessel treated and coronary events in up to 6 months; these results are similar to those of the GRAMI ${ }^{55}$, ESCOBAR ${ }^{56}$, and PAMI-STENT trials. It has already been shown that these advantages do not translate into a reduction in mortality but in nonfatal events. This concept may perfectly apply to our country, which means that the results could be even better if more resources were available; they are frequently not available exclusively due to economic and not technical limitations.

The literature is unanimous in reporting an improvement in ventricular function after a successful primary angioplasty in the short- and long-term. Linderer et al ${ }^{57}$, in a series of 145 patients, showed a $4 \%$ improvement in global ventricular function by the end of 7 months of observation, the improvement being more evident in the patients with worse ejection fraction. Miketic et al ${ }^{58}$ and Salas et al ${ }^{59}$ have shown the same with increases of up to $6 \%$ in the ejection fraction in the 12-month follow-up. Brodie et al ${ }^{60}$, in a series of 1,352 patients, reported that the increase in ventricular function with early reperfusion, within 2 hours of evolution, may reach $6.9 \%$ and drop to $3.1 \%$ for longer periods. The results of our study, despite lack of statistical significance, do not disagree with the results of previous series because the absolute values of improvement in the ejection fraction previously reported do not have relevant clinical significance. On the other hand, we may attribute this lack of gain in ejection fraction to the duration of our intervention, a mean of 3 hours longer, or to limitations in the method of analysis that could not be detected because most studies assess left ventricular function with contrast cineventriculography, different from ours.

Even though our study is limited because it comprises a heterogeneous and nonrandomized group of patients, with biases intrinsic to the design of the study, the analysis of the results of this cohort shows the effectiveness of the method within a local clinical context. It also evidences the borderline of the ideal world of clinical trials, which are carried out in optimal conditions and with unlimited resources, and the actual world with observational studies, which reflect the daily practice with its difficulties and restrictions. 


\section{References}

1. Sarmento Leite R, Gus M. Terapia trombolítica no infarto agudo do miocárdio. Revista da Sociedade de Cardiologia do Rio Grande do Sul 1998; 4: 38-42.

2. American Heart Association: Heart and Stroke Facts: 1996 Stattistical Supplement. Dallas: American Heart Association, 1996: 1-23.

3. Sobel BE, Bresnahn GF, Shell WE, Yorder RD. Estimation of infarct size in man and its relation to prognosis. Circulation 1972; 46: 640-8.

4. Maroko PR, Braunwald E. Modifications of myocardial infarct size after coronary occlusion. Ann Intern Med 1973;79: 720-33.

5. Chazov EI, Matveea LS, Karsch KR, et al. Intracoronary administration of fibrinolysin in acute myocardial infarction. Terapeuticheskii Arkhiv 1976; 48: 8-18.

6. Rentrop KP, Blanke H, Karsch KR, et al. Acute myocardial infarction: intracoronary application of nitroglicerin and streptokinase. Clin Cardiol 1979; 2: 354-63.

7. Fibrinolytic Therapy Trialists' (FTT) Collaborative Group. Indications for fibrinolytic therapy in suspected acute myocardial infarction: collaborative overview of early mortality and major morbidity results from all randomized trials of more than 1000 patients. Lancet 1994; 343: 311-22.

8. Gruppo Italiano per lo Studio Della Streptochinase Nell' Infarto Miocardico (GISSI). Effectiveness of intravenous thrombolitic therapy in acute myocardial infarction. Lancet 1988; 1:397-402.

9. ISIS-2 Collaborative Group. Randomized trial of intravenous streptokinase, oral aspirin, both, or neither among 17187 cases of suspected acute myocardial infarction: ISIS-2. Lancet 1988; II: 349-60.

10. Anglo-Scandinaviam Study of Early Thrombolysis (ASSET). Trial of tissue plasminogen activator for mortality reduction in acute myocardial infarction. Lancet 1988; 2: 525-30.

11. AIMS Trial Study Group. Long-term effects of intravenous anistreplase in acute myocardial infarction: final report of the AIMS study. Lancet 1990; 335: 427-31.

12. Avezum A, Rossi JM, Piegas LS. Terapêutica trombolíticae antitrombótica no infarto agudo do miocárdio: avaliação crítica dos estudos clínicos e recomendações baseadas em evidências. Rev Soc Cardiol do Estado de São Paulo 1996; 3: 285-96.

13. Grupo Italiano per lo Studio Della Streptochinase Nell' Infarto Miocardico (GISSI-2): a factorial randomized trial of alteplase versus streptokinase and heparin versus on heparin among 12490 patients with myocardial infarction. Lancet 1990; 336: 65-71.

14. Anderson JL, Sorensen SG, Moreno FL, et al. Multicenter patency trial of intravenous anistreplase compared with streptokinase in acute myocardial infarction. Circulation 1991; 83: 126-40.

15. Third International Study of Infarct Survival Collaborative Group. ISIS-3: a randomized trial of streptokinase vs tissue plasminogen activators anistreplase and aspirin plus heparin vs aspirin alone among 41299 cases suspected acute myocardial infarction. Lancet 1992; 339: 753-70.

16. The GUSTO investigators. An international randomized trial comparing four thrombolytic strategies for acute myocardial infarction. The GUSTO trial. NEngl J Med 1993; 329: 673-80.

17. Himbert D, Juliard JM, Steg G, et al. Primary coronary angioplasty for acute myocardial infarction with contraindication thrombolysis. Am J Cardiol 1993; 71: 377-81.

18. Muller DW, Topol EJ, Ellis SG, et al. Determinants of the need for early acute interventional in patients treated conservatively after thrombolytic therapy for acute myocardial infarction-TAMI-5 study Group. J Am Coll Cardiol 1991; 18 : 1594-601.

19. Hartzler GO, Rutherford BD, McConahay DR, et al. Percutaneous transluminal coronary angioplasty with and without thrombolytic therapy for treatment of acute myocardial infarction. Am Heart J 1983; 106: 965-73.

20. The TIMI Study Group: Comparision of invasive and conservative strategies following intravenous tissue plasminogen activator in acute myocardial infarction: Results of the Thrombolysis in Myocardial Infarction (TIMI) II Trial. N Engl J Med 1989; 320: 618-28.

21. Flaket GC, Webel RR, Meinhardt S, et al. Emergency angioplasty in acute anterior myocardial infarction. Am Heart J 1989; 118: 1154-60.

22. Beauchamp GD, Vacek JL, Robuck W. Management comparision for acute myocardial infarction: Direct angioplasty versus sequential thrombolysis-angioplasty. Am Heart J 1990; 120: 237-42.

23. Grines CL, Browne KF, Marco J, et al. A comparison of immediate angiopalsty with thrombolytic therapy for acute myocardila infarction- The Primary Angioplasty in myocardial Infarction Study Group. N Engl J Med 1993; 328: 673-9.

24. ZijlstraF, de Boer MJ, Hoornetje JC, et al. A comparision of immediate coronary angioplasty with intravenous streptokinase in acute myocardial infarction. N Engl J Med 1993; 328: 680-4.

25. Gibbons RJ, Holmes DR, Reeder GS, et al. Immediate angioplasty compared with the administration of a thrombolytic agent followed by conservative treatment for myocardial infarction - The Mayo Coronary Care Unit and Catheterization Laboratory Groups. N Engl J Med 1993; 328: 685-91.
26. Ribeiro EE, Silva LA, Carneiro R, et al. Randomized trial of direct coronary angioplasty versus intravenous streptokinase in acute myocardial infarction. J Am Coll Cardiol 1993; 22: 376-80.

27. The GUSTO II Investigators: A clinical trial comparing primary coronary angioplasty with tissue plasminogen activator for acute myocardial infarction. NEngl J Med 1997; 336: 1621-8.

28. O'Neill WW, Brodie BR, Ivanhoe R, et al. Primary coronary angioplasty for acute myocardial infarction (The Primary Angioplasty Registry). Am J Cardiol 1994; 73: 627-34.

29. Every NR, Parsons LS, Hlatky M, et al, for the Myocardial Infarction Triage and Intervention Investigators. A Comparison of Thrombolytic Therapy with Primary Coronary Angioplasty for Acute Myocardial Infarction. N Engl J Med 1996; 335: 1253-60

30. Rogers WJ, Dean LS, Moore PB, et al. Comparision of primary angioplasty versus thrombolytic therapy for acute myocardial infarction. Am J Cardiol 1994; 74: 111-8.

31. Neuhaus KL, Vogt A, Harmjanz D, et al for the ALKK Study Group. Primary angioplasty for acute myocardial infarction: Results from a German multicenter registry. J Am Cardiol 1996; 27: 62A.

32. Weaver WD, Simes RJ, Betriu A, et al for Primary Coronary Angioplasty vs. Thrombolysis Collaboration Group. Comparision of primary angioplasty and intravenous thrombolytic therapy for acute myocardial infarction: A quantitative rewiew. JAMA 1997; 278: 2093-8.

33. Castro I. Avaliação Ecocardiográfica por Quantificação Acústica da Função Sistólica Ventricular Esquerda instantânea e sua Correlação com cineangiocardiografia. Arq Bras Cardiol 1998; 71: 367-8.

34. The TIMI Study Group. The Thrombolysis in myocardial infarction (TIMI) trial: Phase I findings. N Engl J Med 1985; 312: 932-6.

35. Ashmore RC, Luckasen GJ, Larson DG, et al. Immediate Angioplasty for acute myocardial infarction: A community hospital experience. J Invas Cardiol 1999; 11: 61-5.

36. Wharton TP, Mcnamara NS, Fedele FA, et al. Primary angioplasty for the treatment of acute myocardial infarction: experience at two community hospitals without cardiac surgery. J Am Coll Cardiol 1999; 33: 1257-65.

37. Mattos LA, Feres F, Nunes G, et al. Angioplastia primaria para el tratamiento del infarto agudo de miocardio. Resultados imediatos en 601 pacientes. Revista Latinoamericana de Hemodinamia, Angiografia y Terapeutica por Cateterismo 1995; 1: 138-43.

38. Smyth DW, Richards AM, Elliot JM. Direct Angioplasty for myocardial infarcyion: one-year experience in a center with surgical backup 220 miles away. J Invas Cardiol 1997; 9: 324-32.

39. Garcia E, Elizaga J, Pérez-Castellno N, et al. Primary angioplasty versus systemic thrombolysis in anterior myocardial infarction J Am Coll Cardiol 1999; 33 : 605-11.

40. Zahn R, Schiele R, Seidl K, et al. Primary angioplasty in acute myocardial infarction: differences between referred patients and those treated in hospitals with on-site facilities. J Invas Cardiol 1999; 213-9.

41. Azmus AD. Análise dos resultados imediatos e da evolução hospitalar e tardia da angioplastia primária no infarto agudo do miocárdio. Arq Bras Cardiol 1998; 71 : 351-3.

42. Mattos LA, Souza AG, Neto CC, et al. Revascularização coronária percutânea no infarto agudo do miocárdio sem o uso prévio de trombolíticos: análise dos resultados hospitalares no registro CENIC/SBHCI. Rev Bras Cardiol Invas 1999; 7: 7-12.

43. Moscucci M, Bates ER. Cardiogenic schock. Cardiol Clin 1995; 13: 391-406.

44. Hochman JS, Sleeper LA, Weeb JG, et al. Early revascularization in acute myocardial infarction complicated by cardiogenic schock. N Engl J Med 1999; 341 : 625-34.

45. Lange RA, Hillis LD. Should thrombolysis or primary angioplasty be the treatment of choice for acute myocardial infarction? N Eng J Med 1996; 335 : 1311-115.

46. The GUSTO Angiographic Investigators. The effects of tissue plasminogen activator, streptokinase, or both on coronary-artery patency, ventricular function, and survival after acute myocardial infarction. NEngl J Med 1993; 329: 1615-22.

47. Grines CL, Brownwe KF, Marco J, et al. Does primary angioplasty improve the prognosis of patients with diabetes and acute myocardial infarction? J Am Coll Cardiol 1995; (Special issue): 401A.

48. Ohman EM, Callif RM, Topol EJ, et al. Consequences of reoclusion after successful reperfusion therapy in acute myocardial infarction - TAMI Study Group. Circulation 1990; 82: 781-91.

49. Stone GW, Grines CL, Topol EJ. Update on percutaneous transluminal coronary angioplasty for acute myocardial infarction. In: Topol EJ, Serruys PW (ed). Current Review of Interventional Cardiology. Philadelphia: Current Medicine, 1995: 1-56. 
50. Stone GW, Grines CL, Browne KF, et al. Predictors of In-Hospital and 6-month Outcome After Acute Myocardial Infarction in the Reperfusion Era: The Primary Angioplasty in Myocardial Infarction (PAMI) Trial. J Am Coll Cardiol 1995; 25: 370-7.

51. Nunn CM, O'Neill WW, Rothbaum D, et al. Long Term Outcome After Primary Angioplasty: Report From the Primary Angioplasty in Myocardial Infarction (PAMI-I) Trial. J Am Coll Cardiol 1999; 33: 640-6.

52. Zijlstra F, Jan de Boer M, Ottervanger JP, et al. Primary coronary angioplasty versus intravenous streptokinase in acute myocardial infarction: differences in outcome during a mean follow-up of 18 months. Coronary Artery Disease 1994; 5 : 707-12.

53. Rodríguez A. Stent Trials in Acute Myocardial Infartion. J Invas Cardiol 1999 11: 56-60.

54. Antoniucci DA, Santoro GM, Bolognese L, et al. A clinical trial comparing primary stenting of the infarct-related artery with optimal primary angioplasty for acute myocardial infarction. J Am Coll Cardiol 1998; 31: 1234-9.

55. Rodriguez A, Bernardi V,Fernandez M, et al. In-hospital and late results of coro- nary stent versus conventional balloon angioplasty in acute myocardial infarction (GRAMI trial). Am J Cardiol 1998; 81: 1286-91.

56. Suryapranata H, Van't Hof AWJ, Hoorntje JCA, et al. Randomized comparision of coronary stenting with balloon angioplasty in selected patients with acute myocardial infarction. Circulation 1998; 97: 2502-5.

57. Linderer T, Guhl B, Spielberg C, et al. Effect on global and regional left ventricular functions by percutaneous transluminal coronary angioplasty in the chronic stage after myocardial infarction. Am J Cardiol 1992; 69: 997-1002.

58. Miketic S, Carlsson J, Tebbe U. Improvement of global and regional function by percutaneous transluminal coronary angioplasty after myocardial infarction. $\mathbf{J}$ Am Coll Cardiol 1995; 25: 843-7.

59. Salas J, Nuno de la Rosa JA, Martinez J. Follow-up of left ventricular systolic function in the first year following previous infarction. Rev Esp Cardiol 1996; 49: 580-8.

60. Brodie BR, Stuckeiy TD, Wall TC, et all. Importance of time to reperfusion for 30day and late srurvival and recovery of left ventricular function after primary angioplasty for acute myocardial infarction. J Am Coll Cardiol 1998; 32: 1312-9. 